\title{
Modeling of air handling processes in systems of conditioning premises
}

\author{
Maria Zherlykina ${ }^{1, *}$, Elena Smorodina ${ }^{1}$, Gennady Kalabukhov ${ }^{1}$ and Andrey Smolyaninov ${ }^{1}$ \\ ${ }^{1}$ Voronezh State Technical University, 20 let Oktyabrya Street, 84, Voronezh, 394006, Russia
}

\begin{abstract}
Production premises should be provided with air conditioning in order to ensure and maintain required indoor climate parameters for proper technological process running. The paper presents analytical dependences that allow assessing the amount of heat supplied into a premise of processing meat products. A method of determining air parameters was proposed for implementing central conditioning under a technological process running in a premise. For a warm season, the air handling processes that involve or do not involve after-warming were drawn up using $I d$-chart depicting the state of humid air; the need for air recirculation was observed. The need for dehumidification of inlet air was defined and recommendations were proposed to be fulfilled. The method for evaluation of recirculation air amount was amended. For a cold season, the air handling processes that involve or do not involve preheating were drawn up using $I d$-chart depicting the state of humid air; the system of free cooling was proved reasonable to apply.
\end{abstract}

\section{Introduction}

Today, the meat industry is one of the largest and most important sectors of the economy of the Russian Federation. Food industry enterprises perform various types of works concerning the production of meat, canned meat, sausage goods and semi-finished products. Production efficiency largely depends on a number of factors, which include technical equipment and the compliance of the microclimate parameters with the requirements of a technological process in premises of meat processing enterprises $[1,2]$.

In rooms for preparing raw meat, heat and moisture are simultaneously released. Air exchange is determined based on the need for assimilation and removal of harmful substances. It virtually can be accepted that heat exchange and mass transfer are both stationary processes [1].

In production premises, they use such an air conditioning system that implies that air is supplied dispersedly to the upper zone at each season. Air extraction system there is general exhaust, mechanical, air is exhausted from the upper zone. In rooms for raw meat preparation, air recirculation is permitted during all year seasons if air does not contain any pathogenic bacteria, fire and explosion hazardous substances or flue gases [3].

\footnotetext{
* Corresponding author: Kafedravgasu@yandex.ru
} 


\section{Materials and Methods}

The subject of the study is a production premise of a meat industry enterprise located in the city of Kursk: a room for the preparation of meat products. The technological process implies the supply of meat raw materials in the shape of bricks with the temperature of $+2^{\circ} \mathrm{C}$, packed in a plastic film or put on wooden pallets and then in plastic boxes. Dimensions of a brick are $1200 \times 800 \mathrm{~mm}$. Further, bricks are processed moving along the line and then passed to the next room. $21,000 \mathrm{~kg}$ of products are processed every day.

Standard parameters of internal air are the following: room temperature is $+10(+/-2)$ ${ }^{\circ} \mathrm{C}$, relative humidity is $70 \%$. It is worth mentioning that engineering solutions on air conditioning of such premises neglect the accuracy of achieving and maintaining relative humidity.

Calculation of heat gain is executed taking into account the recommendations [4]. Heat balance of a room is calculated according to the following dependence, W:

$$
\sum Q=Q_{1}+Q_{2}+Q_{3}+Q_{4}+Q_{5}+Q_{6},
$$

where Q1 is heat gain got through enclosing structures, $\mathrm{kW}$; Q2 - heat gain from solar radiation, $\mathrm{kW}$; Q3 - heat gain from a product during refrigeration processing; Q4 - heat gain from a ventilation system of a room, $\mathrm{kW}$; Q5 - operational heat gain (from lighting, personnel, electric motors, openings of doors), kW; Q6 - heat gain from products during their cooling, $\mathrm{kW}$, that is calculated through the following analytical dependence:

$$
Q_{5}=\frac{0,278 \cdot \mathrm{M}_{k} \cdot \Delta i}{\tau},
$$

where $\mathrm{Mk}$ is the daily intake of a product in a chamber, $\mathrm{t} ; \Delta \mathrm{i}$ is the difference in the specific enthalpies of a product, $\mathrm{kJ} / \mathrm{kg}, \Delta \mathrm{i}=\mathrm{i} 2-\mathrm{i} 1$, where $\mathrm{i} 1$ is the specific enthalpy corresponding to the initial temperature of a product, $\mathrm{kJ} / \mathrm{kg}$; $\mathrm{i} 2$ is the specific enthalpy corresponding to the final temperature of a product, $\mathrm{kJ} / \mathrm{kg} ; \tau$ is the duration of the refrigeration processing of a product, h; Q6 is a heat gain from packing materials during their cooling, $\mathrm{kW}$, calculated by the following analytical dependence:

$$
Q_{6}=\frac{0,278 \cdot \mathrm{M}_{d} \cdot c_{c} \cdot \Delta t}{\tau},
$$

where $\mathrm{Md}$ is daily supply of packing materials, $\mathrm{t}$, their weight is $20 \%$ of a total cargo weight; $\mathrm{cc}$ is the specific heat capacity of packing materials, $\mathrm{kJ} /(\mathrm{kg} \times \mathrm{K})$, where specific heat capacity is taken according to a material of packing; tl is the temperature of packing materials when cargo is delivered, ${ }^{\circ} \mathrm{C}$; $\mathrm{t} 2$ is the temperature of packing material when cargo is passed out, ${ }^{\circ} \mathrm{C}$.

The present study proposes the central conditioning of a construction site as the most rational approach that allows ensuring the required parameters of air environment for the run of a technological process, as well as providing solutions for energy saving. A mixture of external and internal air in various quantitative proportions is supplied to a production premise. The design of a central air conditioner should provide for the possibility of processing recirculated air. The use of recirculation in air conditioning systems is aimed at preservation of both heat when preheating sections are working and cold while cooling and drying the air. Recirculation is provided by a double mixing chamber (section). The percentage of recirculation can be varied with an electric valve depending on the technological cycle of a premise and a year season. 


\section{Results}

The study was performed for the Production mode for both warm and cold seasons of a year.

The block-scheme of the Production mode for a warm season is presented in Figure 1.

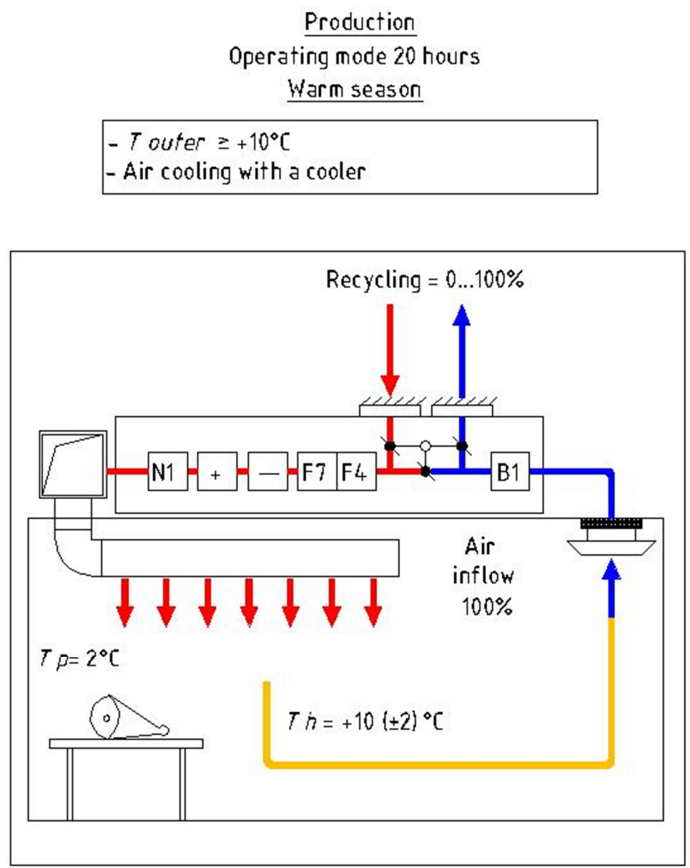

Fig. 1. The block scheme of the Production mode for a warm season: $T_{\text {outer }}$ is the ambient air temperature, ${ }^{\circ} \mathrm{C} ; T_{\text {in }}$ is the inlet air temperature, ${ }^{\circ} \mathrm{C} ; T_{h}$ is the indoor air temperature ${ }^{\circ} \mathrm{C} ; T_{p}$ is the temperature of a product, ${ }^{\circ} \mathrm{C}$; $\mathrm{B} 1$ is the exhaust fan; $\mathrm{N} 1$ is the supply fan; $\mathrm{F} 4$ is the coarse filter; $\mathrm{F} 7$ is the fine filter; "-" is the air chiller; "+" is the air heater.

The air exchange pattern is described above. Full recirculation of air is possible only within the period between the technological cycles, while during the rest of time the flow of external air should be ensured, which must be not less than $350 \ldots 400 \mathrm{~m} 3 / \mathrm{h}$ according to sanitary standards for premises.

In order to determine the parameters of inlet air aiming to achieve a relative humidity of $70 \%$ in a working area of a premise, theoretical studies were performed using an Id-chart of the state of humid air (Figure 2). The value of angular coefficient $\varepsilon, \mathrm{kJ} / \mathrm{kg}$, is determined through the following dependence:

$$
\varepsilon=\frac{I_{h}-I_{\text {outer }}}{d_{h}-d_{\text {outer }}},
$$

where Ih is the specific enthalpy of indoor air of a premise, $\mathrm{kJ} / \mathrm{kg}$; Iouter is the specific enthalpy of outdoor air for a certain period, $\mathrm{kJ} / \mathrm{kg}$; dh is a moisture content in the indoor air of a premise, $\mathrm{g} / \mathrm{kg}$; douter is a moisture content in ambient air for a certain period, $\mathrm{g} / \mathrm{kg}$.

The location of points on the diagram (Figure 2) characterizing the parameters of the inlet (point "N"), mixed (point " $\mathrm{C}$ ") air is determined by the method described in [5]. The specificity of determining the position of point "O", which characterizes the state of air after the chiller, is that in order to obtain the required humidity of internal air in a premise $(70 \%)$, the inlet air must be subcooled and then after-warmed. After-warming is executed 
with a warm-air furnace, which is designed in the central air conditioner. The minimum possible temperature should be determined that can be obtained via a surface chiller under certain parameters of a cooling agent. When using an aqueous 35\% propylene glycol solution, the supply temperature will be $0{ }^{\circ} \mathrm{C}$, while the return temperature will be $+5{ }^{\circ} \mathrm{C}$. As a result of the technical selection of a surface cooler for the case under consideration, the minimum possible air cooling temperature is $+2{ }^{\circ} \mathrm{C}$.

Then the Id-chart is accomplished with a line of humid air during inlet air heating process according to the calculated parameters corresponding with the point $\mathrm{N}$. As can be seen in Figure 2, it is impossible to complete the process of air handling via central air conditioners at point $\mathrm{N}$. The process ends at point N' (line ON'). The treated air at point N' has the temperature of $+6^{\circ} \mathrm{C}$ and relative humidity of $75 \%$. Moreover, the relative humidity at point $\mathrm{N}^{\prime}$ is $4 \%$ higher than the value of point $\mathrm{N}^{\prime}$.

Further, the treated air is subjected to adsorption dehumidifying [6, 7]. Adsorption dehumidifier is notable for its capability to dry low-temperature air. Therefore, devices of this type are used to dehumidify cold premises. This method of air drying has restrictions, since as the sorbent is saturated with moisture, its drying ability decreases, so regeneration is required.

The process of air dehumidifying via adsorbents is depicted on the Id-chart of humid air as a line of constant enthalpy. In this study, it is also impossible to complete the process at point $\mathrm{N}$. The process ends at point N''. The point falls on line NBY that describes the state changing of air in a premise. However, the treated air will have a $0.7^{\circ} \mathrm{C}$ higher temperature than required for supply, and the humidity content will be $0.1 \mathrm{~g} / \mathrm{kg}$ more than required. At this point, the plotting of the required air treatment process on the humid air Id-chart should be completed.

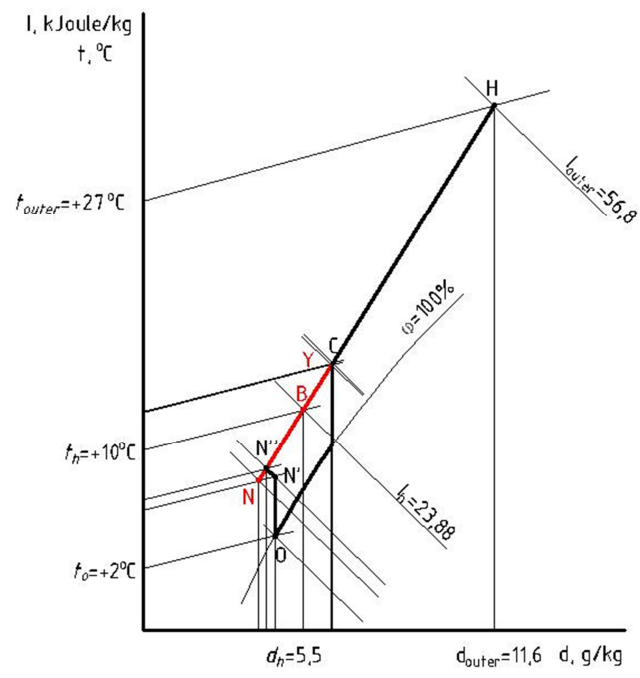

Fig. 2. Plotting the air treatment process on the $I d$-chart for a premise of preparing meat products during a warm season (option 1): NBY is the process air state changing in the production premise; $\mathrm{NY}$ is the process of mixing the external and recirculated (outgoing) air; $\mathrm{Y}$ is the point characterizing the state of outgoing air; $\mathrm{C}$ is the point characterizing the state of the medium after mixing recirculated and outdoor air; $\mathrm{CO}$ is the process of air treatment in the chiller; $\mathrm{ON}^{\prime}$ is the process heating the air in the air-heater; $\mathrm{N}^{\prime} \mathrm{N}$ ' is the adsorption dehumidification of the indoor air.

Calculation of air parameters is performed via application program, the results are presented in table 1 . 
The advantage of the proposed method is the ability to achieve a minimum cooling temperature through mixing the outdoor and recirculated air without a risk of heat exchanger freezing and icing. Comparing with already known calculations [4], the proposed one allows choosing climatic equipment of lower refrigerating power, medium flow rate, reducing aerodynamic and hydraulic characteristics and dimensions.

There is also another way of air handling in the conditioning system during a warm season. The Id-chart of the state of humid air for this option is shown in Figure 3.

The process of after-warming inlet air up to the calculated temperature and humidity cannot be completed at point $\mathrm{N}$, as can be seen from Figure 3. The process ends at point $\mathrm{N}$ "' (line ON"'). The point falls on line NBY, which characterizes the air state changing in the premise. However, the treated air will have a temperature of $1.5{ }^{\circ} \mathrm{C}$ higher than necessary to supply, while the humidity content will be $0.4 \mathrm{~g} / \mathrm{kg}$ more than required. The plotting of the required air treatment process on the Id-chart of humid air is finished there. The calculation of the process was performed via application program for a warm season, the results are presented in table 2 .

Table 1. Calculation of the air treatment process in the system of air conditioning of premises for meat products processing for a warm season (option 1).

\begin{tabular}{|l|l|l|l|l|l|l|l|}
\hline \multicolumn{1}{|c|}{ Item } & & & \multicolumn{5}{c|}{ Points } \\
\hline & & & 1 & 2 & 3 & 4 & 5 \\
\hline Initial data & & & $\mathrm{H}$ & $\mathrm{Y}$ & $\mathrm{C}$ & $\mathrm{O}$ & $\mathrm{N}$ \\
\hline Temperature & $t$ & ${ }^{\circ} \mathrm{C}$ & 27.0 & 12,5 & & 2.0 & 6.0 \\
\hline Humidity & $\varphi$ & $\%$ & & & & & \\
\hline $\begin{array}{l}\text { Humidity } \\
\text { content }\end{array}$ & $d$ & $\mathrm{~g} / \mathrm{kg}$ & & & & & \\
\hline Enthalpy & $\mathrm{I}$ & $\mathrm{kJ} / \mathrm{kg}$ & 56.8 & 28,3 & & & \\
\hline Process & & & & & Mixture & Cold & Heat \\
\hline Consumption & $\mathrm{V}$ & $\mathrm{m}^{3} / \mathrm{h}$ & 400 & 39600 & & & \\
\hline Power & $\mathrm{P}$ & $\mathrm{kW}$ & & & & & \\
\hline Result & & & 1 & 2 & 3 & 4 & 5 \\
\hline Temperature & $t$ & ${ }^{\circ} \mathrm{C}$ & 27.0 & 12.5 & 12.65 & 2.0 & 6.0 \\
\hline Humidity & $\varphi$ & $\%$ & 50 & 66 & 66 & 100 & 75 \\
\hline $\begin{array}{l}\text { Humidity } \\
\text { content }\end{array}$ & $d$ & $\mathrm{~g} / \mathrm{kg}$ & 11.57 & 6.21 & 6.26 & 4.56 & 4.56 \\
\hline Enthalpy & $I$ & $\mathrm{~kJ} / \mathrm{kg}$ & 56.80 & 28.30 & 28.59 & 13,43 & 17.51 \\
\hline Density & $\rho$ & $\mathrm{kg} / \mathrm{m}^{3}$ & 1.12 & 1.18 & 1.18 & 1,22 & 1,20 \\
\hline Consumption & $\mathrm{V}$ & $\mathrm{m}^{3} / \mathrm{h}$ & 435 & 40658 & 41093 & 39455 & 40029 \\
\hline Consumption $*$ & $\mathrm{~V}$ & $\mathrm{~m} / \mathrm{h}$ & 400 & 39600 & 40000 & 40000 & 40000 \\
\hline Power & $\mathrm{P}$ & $\mathrm{kW}$ & & & & -202.04 & 54.32 \\
\hline Humid inflow & $\mathrm{q}_{\mathrm{w}}$ & $\mathrm{kg} / \mathrm{h}$ & & & 0,00 & -81.94 & 0.00 \\
\hline
\end{tabular}

Remark. Atmospheric pressure is $96.8 \mathrm{kPa}$, cooling agent temperature is $2.50^{\circ} \mathrm{C}$. 


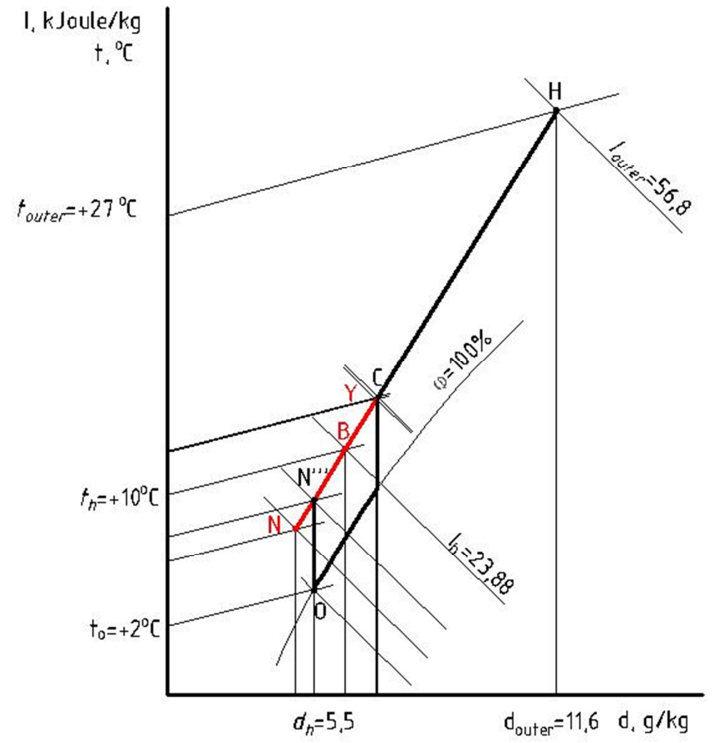

Fig. 3. Plotting the air treatment process on the $I d$-chart for a premise of preparing meat products during a warm season (option 2): NBY is the process air state changing in the production premise; $\mathrm{NY}$ is the process of mixing the external and recirculated (outgoing) air; $\mathrm{Y}$ is the point characterizing the state of outgoing air; $\mathrm{C}$ is the point characterizing the state of air after mixing recirculated and outdoor air; $\mathrm{CO}$ is the process of air handling in the cooler; $\mathrm{ON}^{\text {" " }}$ is the process heating the air in the air heater.

It is worth mentioning that the premise under study does not require the maintenance of precision parameters (temperature accuracy $+/-0.5^{\circ} \mathrm{C}$, humidity accuracy $+/-1 \%$ ).

It should be clarified that for the proposed inlet air handling schemes used in conditioning systems of meat processing premises, it is not recommended to use adsorption dehumidification in a warm season when parameters deviate from the calculated ones (moisture content by $0.1 \mathrm{~g} / \mathrm{kg}$, relative humidity by $4 \%$, temperature by $0.7^{\circ} \mathrm{C}$ ).

The block scheme of the Production mode for a cold season is shown in Figure 4.

In terms of energy saving, free cooling system is the most rational solution to apply. The system implies using cold ambient air. To implement this solution in the air conditioning system, one needs to consider the moment when external air temperature reaches $-6{ }^{\circ} \mathrm{C}$ as the starting point of free cooling system's work. Inlet air passes through the two-stage filtration: the first is cooling with ambient air, the second is heating it by a warm-air furnace and then feeding into the room with outlet temperature of $+6{ }^{\circ} \mathrm{C}$. Complete air recirculation is possible only within periods between technological cycles, just like in a warm season, the rest of time external air flow for a premise must be not less than $350 \ldots 400 \mathrm{~m}^{3} / \mathrm{h}$.

Table 2. Calculation of the air handling process in an air conditioning system of a premise for meat products processing for a warm season (option 2).

\begin{tabular}{|l|l|l|l|l|l|l|l|}
\hline \multicolumn{1}{|c|}{ Item } & & & \multicolumn{5}{c|}{ Points } \\
\hline & & & 1 & 2 & 3 & 4 & 5 \\
\hline Initial data & & & $\mathrm{H}$ & $\mathrm{Y}$ & $\mathrm{C}$ & $\mathrm{O}$ & $\mathrm{N}$ \\
\hline Temperature & $t$ & ${ }^{\circ} \mathrm{C}$ & 27.0 & 12.5 & 12.65 & 2.0 & 7.5 \\
\hline Humidity & $\varphi$ & $\%$ & & & & & \\
\hline Humidity content & $d$ & $\mathrm{~g} / \mathrm{kg}$ & & & & & \\
\hline Enthalpy & $I$ & $\mathrm{~kJ} / \mathrm{kg}$ & 56,8 & 28,3 & & & \\
\hline
\end{tabular}




\begin{tabular}{|l|l|l|l|l|l|l|l|}
\hline Process & & & & & Mixture & Cold & $\begin{array}{l}\text { Heatin } \\
\mathrm{g}\end{array}$ \\
\hline Consumption & $\mathrm{V}$ & $\mathrm{m}^{3} / \mathrm{h}$ & 400 & 39600 & & & \\
\hline Power & $\mathrm{P}$ & $\mathrm{kW}$ & & & & & \\
\hline Result & & & 1 & 2 & 3 & 4 & 5 \\
\hline Temperature & $t$ & ${ }^{\circ} \mathrm{C}$ & 27.0 & 12.5 & 12.65 & 2.0 & 7.5 \\
\hline Humidity & $\varphi$ & $\%$ & 50 & 66 & 66 & 100 & 68 \\
\hline Humidity content & $d$ & $\mathrm{~g} / \mathrm{kg}$ & 11.57 & 6.21 & 6.26 & 4,56 & 4.56 \\
\hline Enthalpy & $I$ & $\mathrm{~kJ} / \mathrm{kg}$ & 56.8 & 28.3 & 28.59 & 13,43 & 19.03 \\
\hline Density & $\rho$ & $\mathrm{kg} / \mathrm{m}^{3}$ & 1.12 & 1.18 & 1,18 & 1,22 & 1.20 \\
\hline $\begin{array}{l}\text { Temperature of } \\
\text { wet-bulb } \\
\text { thermometer }\end{array}$ & $t_{v}$ & ${ }^{\circ} \mathrm{C}$ & 19.28 & 9.19 & 9.31 & 2.00 & 4.91 \\
\hline Consumption & $\mathrm{V}$ & & & & & & \\
\hline Consumption* & $\mathrm{V}$ & $\mathrm{m}^{3} / \mathrm{h}$ & 435 & 40658 & 41093 & 39455 & 40244 \\
\hline Power & $\mathrm{P}$ & $\mathrm{kW}$ & & & & -202.04 & 74.69 \\
\hline Humid inflow & $\mathrm{q}_{\mathrm{w}} / \mathrm{h}$ & $\mathrm{kg} / \mathrm{h}$ & & & 0.00 & -81.94 & 0.00 \\
\hline
\end{tabular}

Remark: Atmospheric pressure is $96.8 \mathrm{kPa}$, cooling agent's temperature is $2.50^{\circ} \mathrm{C}$.

The existing methods for modeling air handling processes have the following drawbacks: the calculation of free cooling system during direct-flow mode, the overspend of cooling agent, significant amounts of thermal power and overall sizes of climate control equipment.

A theoretical study during a cold season with a calculated ambient temperature of 0.98 does not enable assessing the capability of central air conditioners to provide a serviced premise with required relative humidity of $70 \%$ and the temperature prescribed in technological standards for the design of meat industry enterprises.

Production

Operating mode 20 hours

Cold season

Cold season
\begin{tabular}{|l} 
- Toufer $\leq-6^{\circ} \mathrm{C}$ \\
- Heating is possible \\
- Out door air cooling (free colling)
\end{tabular}

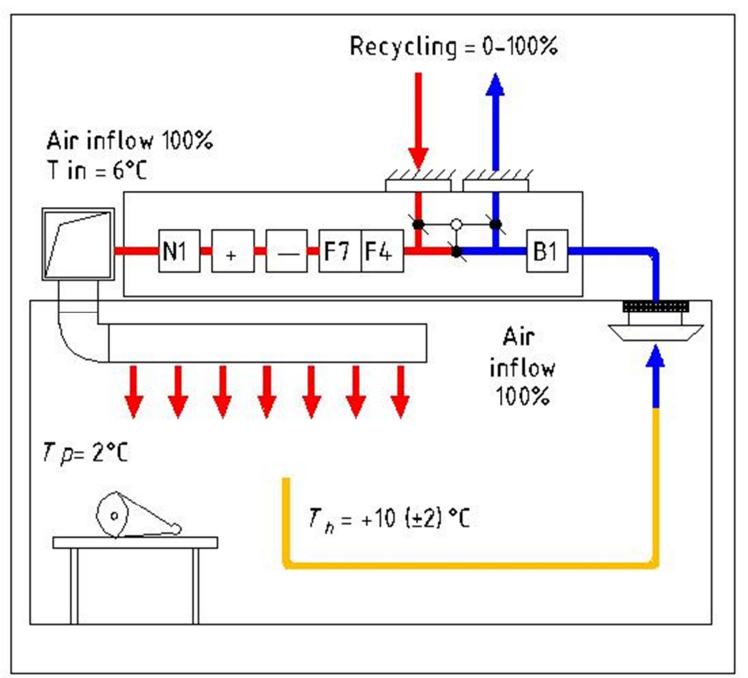

Fig. 4. Block scheme of the Production mode for a cold season: B1 - exhaust fan; N1 - supply fan; F4 - coarse filter; F7 - fine filter; "-" - air chiller; "+" - air heater. 
In order to solve the problem, air handling process is plotted on the Id-chart for a cold season. The methodology is described for a system that allows providing a constant temperature and humidity regime in a premise and works based on cold ambient air. The air conditioning system maintains the set air parameters and provides such amount of ambient air that is prescribed by sanitary standards, taking into account the reduced room temperature without heating equipment use. The drawing up of the process is shown in Figure 5.

The plotting method includes determining the position of points $\mathrm{N}$ and $\mathrm{B}$, characterizing the state of external and internal air. The position of point $\mathrm{Y}$ that characterizes the state of outlet air is determined, then the position of point $\mathrm{N}$ that describes the state of inlet air is determined. The position of point $\mathrm{C}$ characterizing the state of outlet air of a mixing chamber is found. When mixing indoor and outdoor air in the cold season, cooling is executed according to free cooling system $[8,9,10]$. Cooling occurs due to the outdoor cold. The system operates on a variable quantitative ratio of external and internal air removed from a premise [11].

Next, the process of after-warming inlet air up to the calculated parameters is drawn up in the Id-chart of humid air (line ON). The calculated parameters correspond to the previously plotted point $\mathrm{N}$ belonging to line NBY - a process in the premise. The process will be completed successfully, the air parameters will be: temperature is at least $+10{ }^{\circ} \mathrm{C}$, relative humidity is $70 \%$, therefore, the parameters required by the technology are possible to maintain in the premise. Figure 5 shows that after-warming is only $1.11{ }^{\circ} \mathrm{C}$. At this point, the draw up of the required air handling process in the Id-chart of humid air is completed.

The study on an air handling process was performed for other ambient temperatures ranging from ta to $-6^{\circ} \mathrm{C}$.

The change in ambient temperature on the Id-chart will is shown along the line $\mathrm{d}=$ const. The goal is to determine the effective percentage of recirculation for different ambient temperatures, as well as to adjust the selection of a heating section. These processes are also shown in Figure 5: under external temperature touter of $-20^{\circ} \mathrm{C}$, the effective percentage of recirculation is $80 \%$, after-warming is by $0.27^{\circ} \mathrm{C}$; under $-15^{\circ} \mathrm{C}$, recirculation is $75 \%$, afterwarming is by $0.32{ }^{\circ} \mathrm{C}$; under $-6^{\circ} \mathrm{C}$, recirculation is $60 \%$, after-warming is by $0.62{ }^{\circ} \mathrm{C}$.

The proposed method has the following benefits: the use of data on the free cooling system when selecting a heater, reducing the thermal power, dimensions, aerodynamic and hydraulic characteristics of climatic control equipment.

The calculation of the process was performed via application program for a warm season, the results are presented in table 3.

It should be noted that the calculated effective percentage of air recirculation is advised to use according to ambient air temperature $[3,12,13,14]$. The calculations showed that the interval of operation time of a heater section during a cold season is extremely small.

Figure 5 shows that within a temperature range from $-24{ }^{\circ} \mathrm{C}$ to $-15{ }^{\circ} \mathrm{C}$, the process of mixing the ambient and outlet air passes through the area of oversaturated air: the "fog zone", where water is suspended in air in a liquid or solid phase. "Fog zone" is the area of the Id-chart lying below the curve $\varphi=100 \%$. Processes inside this area are considered not feasible in air conditioning systems [8]. 


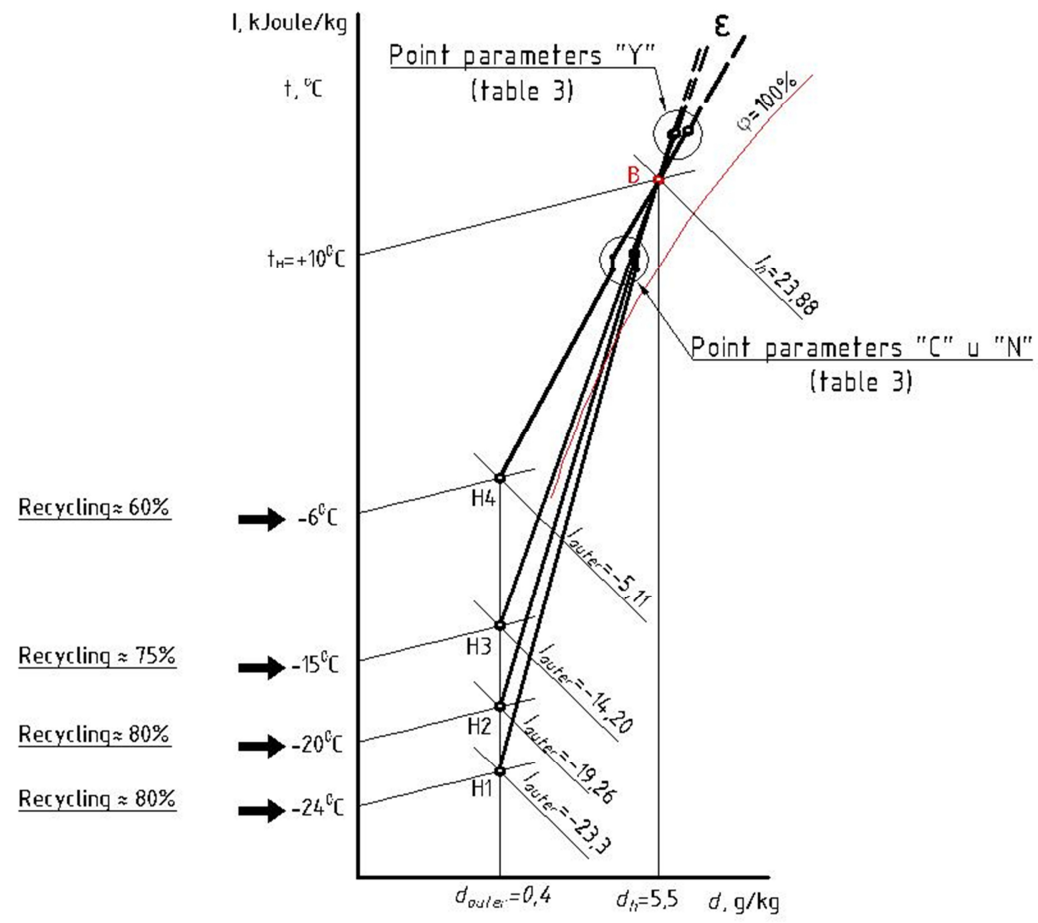

Fig. 5. Plotting the air treatment process on the $I d$-chart for a premise of preparing meat products during a cold season: $\mathrm{B}$ - required state of air in a premise; $\mathrm{H}_{\mathrm{i}} \mathrm{Y}_{\mathrm{i}}$ - process of mixing ambient and recirculated air; $\mathrm{C}_{\mathrm{i}}$ - process of air handling after mixing recirculated and ambient air; $\mathrm{C}_{\mathrm{i}} \mathrm{N}_{\mathrm{i}}-$ process of air handling in the air heater.

Table 3. Calculation of air handling process in air conditioning system of premises for processing meat products during cold season.

\begin{tabular}{|c|c|c|c|c|c|c|c|c|c|c|}
\hline \multirow[t]{2}{*}{ Item } & & & \multicolumn{4}{|c|}{ Points } & \multicolumn{4}{|c|}{ Points } \\
\hline & & & 1 & 2 & 3 & 4 & 1 & 2 & 3 & 4 \\
\hline & & & $\mathrm{H}_{3}$ & $\mathrm{Y}_{3}$ & $\mathrm{C}_{3}$ & $\mathrm{~N}_{3}$ & $\mathrm{H}_{4}$ & $\mathrm{Y}_{4}$ & $\mathrm{C}_{4}$ & $\mathrm{~N}_{4}$ \\
\hline Process & & & & & $\begin{array}{c}\text { Mixtur } \\
\mathrm{e}\end{array}$ & $\begin{array}{c}\text { Heatin } \\
\text { g }\end{array}$ & & & $\begin{array}{c}\text { Mixtur } \\
\mathrm{e}\end{array}$ & $\begin{array}{c}\text { Heatin } \\
\mathrm{g}\end{array}$ \\
\hline Temperature & $t$ & ${ }^{\circ} \mathrm{C}$ & -15 & 12.5 & 5.7 & 6.0 & -6.0 & 12.5 & 5.4 & 6.0 \\
\hline Humidity & $\varphi$ & $\%$ & 37 & 63 & 77 & 75 & 16 & 67 & 69 & 66 \\
\hline $\begin{array}{c}\text { Humidity } \\
\text { content }\end{array}$ & $d$ & $\mathrm{~g} / \mathrm{kg}$ & 0.4 & 5.8 & 4.5 & 4.5 & 0.4 & 6.2 & 3.9 & 3.9 \\
\hline Enthalpy & $I$ & $\begin{array}{c}\mathrm{kJ} / \mathrm{k} \\
\mathrm{g}\end{array}$ & -14.2 & 27.3 & 16.9 & 17.3 & -5.1 & 28.2 & 15.3 & 15.9 \\
\hline Density & $\rho$ & $\mathrm{kg} / \mathrm{m}$ & 1.33 & 1.20 & 1.23 & 1.23 & 1.29 & 1.20 & 1.23 & 1.23 \\
\hline $\begin{array}{l}\text { Wet-bulb } \\
\text { thermometer } \\
\text { temperature }\end{array}$ & $t_{v}$ & ${ }^{\circ} \mathrm{C}$ & -16.3 & 8.9 & 4.0 & 4.1 & -9.3 & 9.3 & 3.1 & 3.4 \\
\hline $\begin{array}{c}\text { Consumptio } \\
n\end{array}$ & V & $\mathrm{m}^{3} / \mathrm{h}$ & 9025 & $\begin{array}{c}3022 \\
0 \\
\end{array}$ & 39246 & 39292 & $\begin{array}{c}1447 \\
6 \\
\end{array}$ & $\begin{array}{c}2469 \\
4 \\
\end{array}$ & 39171 & 39258 \\
\hline $\begin{array}{c}\text { Consumptio } \\
\mathrm{n}^{*}\end{array}$ & V & $\mathrm{m}^{3} / \mathrm{h}$ & $\begin{array}{c}1000 \\
0\end{array}$ & $\begin{array}{c}3000 \\
0 \\
\end{array}$ & 40000 & 40000 & $\begin{array}{c}1550 \\
0 \\
\end{array}$ & $\begin{array}{c}2450 \\
0 \\
\end{array}$ & 40000 & 40000 \\
\hline Power & $\mathrm{P}$ & $\mathrm{kW}$ & & & & 4.4 & & & & 8.4 \\
\hline
\end{tabular}




\begin{tabular}{|c|c|c|c|c|c|c|c|c|c|c|}
\hline $\begin{array}{l}\text { Humidity } \\
\text { inflow }\end{array}$ & $\begin{array}{l}\mathrm{q} \\
\mathrm{w}\end{array}$ & $\mathrm{kg} / \mathrm{h}$ & & & 0,0 & 0.0 & & & 0.0 & 0.0 \\
\hline Process & & & & & $\begin{array}{c}\text { Mixtur } \\
\mathrm{e}\end{array}$ & $\underset{\mathrm{g}}{\text { Heatin }}$ & & & $\begin{array}{c}\text { Mixtur } \\
\mathrm{e}\end{array}$ & $\begin{array}{c}\text { Heatin } \\
\mathrm{g}\end{array}$ \\
\hline Temperature & $t$ & ${ }^{\circ} \mathrm{C}$ & -24 & 12.5 & 4.9 & 6.0 & $-20,0$ & 12.5 & 5.7 & 6.0 \\
\hline Humidity & $\varphi$ & $\%$ & 87 & 62 & 84 & 78 & 59 & 62 & 79 & 78 \\
\hline $\begin{array}{c}\text { Humidity } \\
\text { content }\end{array}$ & $d$ & $\mathrm{~g} / \mathrm{kg}$ & 0,4 & 5.7 & 4.6 & 4.6 & 0,4 & 5.7 & 4.6 & 4.6 \\
\hline Enthalpy & $I$ & $\begin{array}{c}\mathrm{kJ} / \mathrm{k} \\
\mathrm{g}\end{array}$ & $-23,3$ & 27.1 & 16.5 & 17.6 & $-19,3$ & 27.1 & 17.4 & 17.6 \\
\hline Density & $\rho$ & $\mathrm{kg} / \mathrm{m}$ & 1,38 & 1.20 & 1.23 & 1.23 & 1,36 & 1.20 & 1.23 & 1.23 \\
\hline $\begin{array}{l}\text { Wet-bulb } \\
\text { thermometer } \\
\text { temperature }\end{array}$ & $t_{v}$ & ${ }^{\circ} \mathrm{C}$ & $-24,1$ & 8.8 & 3.8 & 4.3 & $-20,6$ & 8.8 & 4.2 & 4.3 \\
\hline $\begin{array}{c}\text { Consumptio } \\
n\end{array}$ & V & $\mathrm{m}^{3} / \mathrm{h}$ & 7317 & $\begin{array}{c}3182 \\
8\end{array}$ & 39146 & 39301 & 7434 & $\begin{array}{c}3182 \\
8 \\
\end{array}$ & 39263 & 39301 \\
\hline $\begin{array}{c}\text { Consumptio } \\
n^{*}\end{array}$ & $\mathrm{~V}$ & $\mathrm{~m}^{3} / \mathrm{h}$ & 8400 & $\begin{array}{c}3160 \\
0 \\
\end{array}$ & 40000 & 40000 & 8400 & $\begin{array}{c}3160 \\
0\end{array}$ & 40000 & 40000 \\
\hline Power & $\mathrm{P}$ & $\mathrm{kW}$ & & & & 15.0 & & & & 3.7 \\
\hline $\begin{array}{c}\text { Humidity } \\
\text { inflow }\end{array}$ & $\begin{array}{l}\mathrm{q} \\
\mathrm{w}\end{array}$ & $\mathrm{kg} / \mathrm{h}$ & & & 0.0 & 0.0 & & & 0.0 & 0.0 \\
\hline
\end{tabular}

To bring the process to the area where the system can operate, it is necessary to ensure the preheating of ambient air within the temperature range from $-24{ }^{\circ} \mathrm{C}$ to $-15{ }^{\circ} \mathrm{C}(1 \mathrm{st}$ heating step). It is recommended to preheat such low air temperatures with the use of a warm-air furnace in order to avoid freezing of cooling agent in case of emergency. The range of recirculation within a cold season is $60 \ldots 75 \%$. An air conditioning system involving preheating is shown in Figure 6.

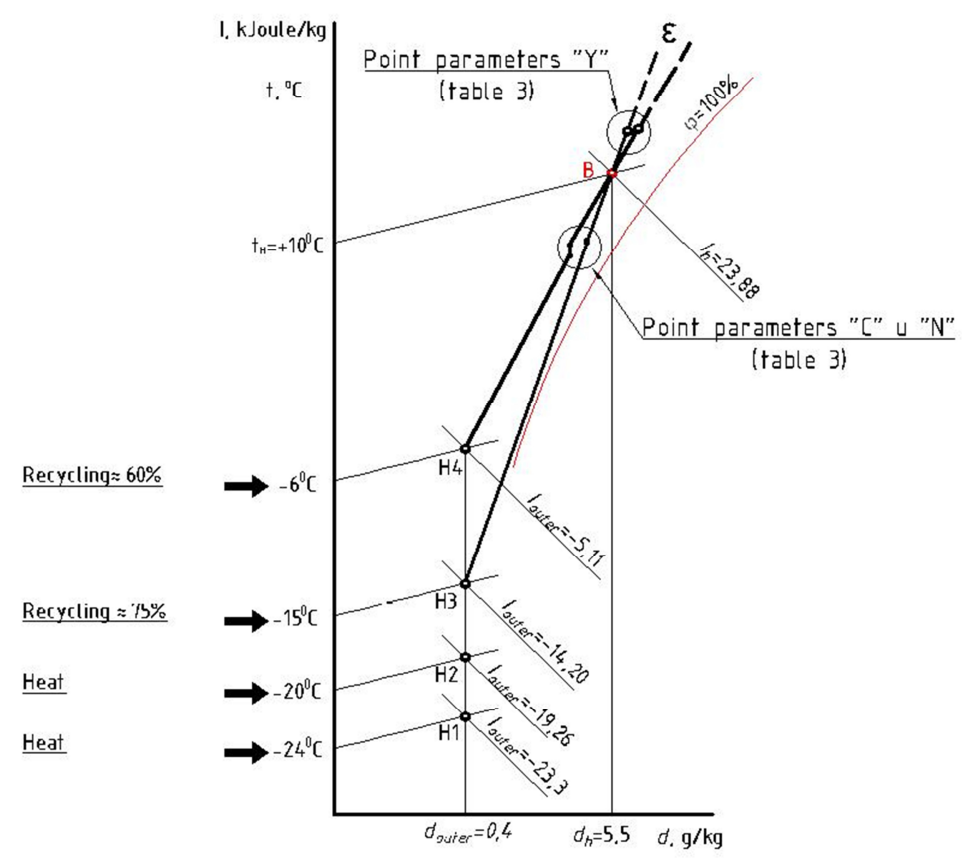


Fig. 6. Plotting on the $I d$-chart of the air handling process with preheating for the premise of meat products processing during a cold season.

\section{Conclusions}

The amount of inlet air for conditioning systems of premises for processing meat products must be determined taking into account the elaborated recommendations, provided as an analytical dependence (1).

During a warm season under the Production mode, it is advisable to use air recirculation, providing air volume inlet prescribed by sanitary norms. This will contribute to energy saving during the operation of an engineering system, also will improve the conditions for its operation. This method is universally applicable because of the variability of solutions under various climatic conditions and the heat-humidity state of air in a premise. For those cases, when air conditioning process cannot be executed, which is proved by plotting it on an Id-chart, the scheme for air handling in an air conditioning system with warming was developed.

For a cold season under technological Production mode, air conditioning should be carried out with the use of cold ambient air. This system is called "free cooling". For cases when air handling processes are not feasible, which can be proved by plotting them on the Id-chart, the air handling scheme in an air conditioning system with preheating was developed.

One should know that the developed recommendations are designed only for the Production cycle, which is a part of a bigger technological process running in a premise for preparing meat products. To assess the operation of air conditioning system comprehensively, one should perform studies for the cycles of Washing and Drying.

\section{References}

1. V. Murgul, D. Vuksanovic, N. Vatin, V. Pukhkal, Applied Mechanics and Materials 635-637, 370-376 (2014) DOI:10.4028/www.scientific.net/AMM.635-637.370

2. V. Murgul, D. Vuksanovic, N. Vatin, V. Pukhkal, Applied Mechanics and Materials 680, 524-528 (2014) DOI:10.4028/www.scientific.net/AMM.680.524

3. V. Pukhkal, N. Vatin, V. Murgul, Applied Mechanics and Materials 633-634, 10771081 (2014) DOI:10.4028/www.scientific.net/AMM.633-634.1077

4. A. Abd Aziz, D. Sumiyoshi, Y. Akashi, MATEC Web of Conferences 225, 04016 (2018) DOI: https://doi.org/10.1051/matecconf/201822504016

5. K.F. Fong, C.K. Lee, Z. Lin, Renewable Energy 131, 413-421 (2019) DOI: https://doi.org/10.1016/j.renene.2018.07.065

6. A. Meiss, J. Feijó-Muñoz, M.A. García-Fuentes, Energy and Buildings 67, 88-96 (2013) DOI: https://doi.org/10.1016/j.enbuild.2013.08.016

7. A. Mikuckas, D. Ciuzas, T. Prasauskas, et al., Applied Mathematical Modelling 42, 290-299 (2017) DOI: https://doi.org/10.1016/j.apm.2016.10.030

8. T.C. Callari, N. McDonald, B. Kirwan, K. Cartmale, Safety Science 120, 838-849 (2019) DOI: https://doi.org/10.1016/j.ssci.2019.08.027

9. S.A. Gómez, A. Goron, A. Groza, I.A. Letia, Expert Systems with Applications 44, 367-385 (2016) DOI: https://doi.org/10.1016/j.eswa.2015.09.027

10. B. Yang, A.K. Melikov, A. Kabanshi et al., Energy and Buildings 2021, 109359 (2019) DOI: https://doi.org/10.1016/j.enbuild.2019.109359 
11. H.J. Rickenbacker, W.O. Collinge, V. Hasik, et al., Sustainable Cities and Society 52, 101831 (2020) DOI: https://doi.org/10.1016/j.scs.2019.101831

12. T. Lehouillier, F. Soumis, J. Omer, C. Allignol, Computers \& Industrial Engineering 99, 269-279 (2016) DOI: https://doi.org/10.1016/j.cie.2016.07.025

13. W.W. Che, Ch.Y. Tso, L. Sun, et al., Energy and Buildings 20115, 202-215 (2019) DOI: https://doi.org/10.1016/j.enbuild.2019.06.029

14. V.G. Gagarin, K.I. Lushin, V.V. Kozlov, A.Y. Neklyudov, Procedia Engineering 1462016, 103-111 (2016) DOI: https://doi.org/10.1016/j.proeng.2016.06.359 